\title{
Ethnologies
}

\section{A Heritage of Light. By Loris S. Russell. (University of Toronto Press: Toronto, 2002. Pp. xiii+344, photos, ISBN 0-8020-3765-8)}

\section{Kate Butler}

Volume 27, numéro 2, 2005

Terrains disputés

Contested Geographies

URI : https://id.erudit.org/iderudit/014052ar

DOI : https://doi.org/10.7202/014052ar

Aller au sommaire du numéro

\section{Éditeur(s)}

Association Canadienne d'Ethnologie et de Folklore

ISSN

1481-5974 (imprimé)

1708-0401 (numérique)

Découvrir la revue

Citer ce compte rendu

Butler, K. (2005). Compte rendu de [A Heritage of Light. By Loris S. Russell. (University of Toronto Press: Toronto, 2002. Pp. xiii+344, photos, ISBN

0-8020-3765-8)]. Ethnologies, 27(2), 269-271. https://doi.org/10.7202/014052ar

Ce document est protégé par la loi sur le droit d'auteur. L'utilisation des services d'Érudit (y compris la reproduction) est assujettie à sa politique d'utilisation que vous pouvez consulter en ligne.

https://apropos.erudit.org/fr/usagers/politique-dutilisation/ 
fetish?" and the answers to the question are fairly similar in content and phrasing $(18,49)$. Other editing problems are relatively minor, but still potentially confusing. For instance, while discussing the word "fetish," Ellis asserts that "originally" it was used with a particular meaning in a particular context, but then goes on to give a previous use and to discuss cognates and earlier forms of the word (51). The number of problems of this type in the book, while not outrageous, does seem to be higher than one would usually expect in a text of this length. Since the overall organisation of this book is quite good, however, Ellis' main ideas are, despite these problems, reasonably easy to follow. Confusing discussion is limited to relatively unimportant points.

Overall, despite some minor problems, this is a good book that is likely to be of significant use to scholars and of interest to many general readers. It takes a complex, nuanced, and balanced look at topics that are currently highly loaded in our culture and draws some interesting conclusions.

Anne Lafferty Memorial University St. John's, Newfoundland

\section{Reference}

Ellis, Bill. 2000. Raising the Devil: Satanism, New Religions, and the Media. Lexington: University Press of Kentucky.

A Heritage of Light. By Loris S. Russell. (University of Toronto Press: Toronto, 2002. Pp. xiii+344, photos, ISBN 0-8020-3765-8)

When A Heritage of Light first appeared in 1968, it might have seemed to come from an unusual source. Loris Russell's background was largely in the fields of geology and palaeontology, with his work in Canada's Badlands culminating in the book Dinosaur Hunting in Western Canada. His interest in Canadian folklore and material culture took flight in the late 1950s when he was Acting Director of Human History at the National Museum of Canada, and this interest eventually came to focus on lamps and lighting. Even after he returned to the field of life sciences, his interest in lighting continued to grow in his own time and resulted in significant research, a sizable collection of lamps and this book, which has just recently been republished with a new forward by Janet Holmes. 
The product of a passion for one quite particular topic, A Heritage of Light really exudes excitement, boasting chapters with titles such as, "When Whale Oil Was King" and "Those New-Fangled Lamps". The chief focus of the book is on the lamps themselves and the ways in which they worked (or often didn't work). Russell is meticulous in detailing each element of every lamp, from wicks to fuel tubes, not only with descriptions, but also with an extensive collection of photos. These images are highly useful for a person with no background in the technical workings of lamps. The photos also allow a reader to enjoy the aesthetics of these pieces, as many of them that might have been designed merely to be practical are also quite attractive. Unfortunately, all of the photos only appear in black and white; a small selection of colour plates would have made a nice addition.

Russell's book takes the form of a journey through almost one hundred years of Canadian history, from the splint and the candle to the coming of electricity, focusing on the changes brought about by different lamp designs as well as those wrought by different sorts of fuel, including whale oil, dangerous burning fluid, and kerosene. His chief interest, beyond the workings of the lamps themselves, is in the men who invented the lamps, the experiments that failed and those that succeeded. He traces these men through the system of patents in both Canada and the United States, highlighting the similarities and differences in the two systems.

The author's interest in experimentation really comes through in one of the most exciting aspects of the book, in which Russell details his attempts to make some of the lamps that he describes come to life again as it were. Not all of his experiments are successes, and in some cases, he cannot determine how the lamps worked or worked efficiently. By attempting to return these pieces to their original use, he brings them out of the realm of curios, which anyone might purchase in an antique shop to place on a shelf and just look at.

My chief complaint with Russell's book centres on its lack of a human element. Of course, every lamp featured in the book was invented by a human mind and used by human hands, but I would have liked to see more information on exactly how they were used and by whom. Russell falls more on the side of the patents and inventors; the history side of the folklore versus history debate. That is not to say though that there are not all sorts of interesting tidbits to be gleaned from letters and 
stories (taken from newspaper accounts of the day) of fires caused by careless use of lamps. A picture of a slightly grotesque, yet strangely charming, lamp which features the head of a plump woman makes one wonder about the family who owned it and just what they thought of it. Newspaper ads communicate all the excitement that was felt, or a least that shopkeepers hoped would be felt, each time a new lamp appeared on the market.

One of the pieces in the book that interested me the most covered the blending of lighting and folk medicine. Russell examines the "VapoCresolene" lamp that was reputed to give off a vapour that cured everything from hay fever to measles. Russell further states that he discovered the lamp to have no actual medical benefits, but the story is hugely interesting nonetheless.

Perhaps it is not surprising to find Russell's book focused on the technical workings of these pieces, coming as he does from what one might call a more scientific background in palaeontology. When his interest in folklore surfaced, it settled on one very specific aspect of material culture. This book is certainly invaluable to anyone interested in this period in Canadian history though, as it does make one realize the way in which light affects the way in which people view the world and live their lives. Russell hints at the difference it makes for a person to have light of a high enough quality to sew or read by, but I feel there is far more interesting work to be focused on this topic.

A Heritage of Light is a well-organized chronological look at the history of lamps and lighting in Canada, featuring an extensive group of photos, diagrams and illustrations. Russell's comprehensive glossary is also worth noting and should be regularly consulted in order to keep all of the components and varieties of lamps clear in one's mind. This volume will likely never have a place as a piece of pure pleasure reading, unless the reader shares Russell's passion for the topic already. That said, his excitement certainly heightened this reader's interest. All in all, it is a classic on the topic and I'm glad to see that it has been republished.

Kate Butler 